\title{
ANALYSIS OF FACTORS AFFECTING BEEF SUPPLY IN THE DISTRICT DELI SERDANG
}

\author{
G M T Siahaan, Hasnudi, E Mirwandhono, M Tafsin, N Ginting \\ Animal Production Sudy Program, Faculty of Agriculture, University of Sumatera \\ Utara, Medan 20155 \\ E-mail: gilbert9haan@gmail.com
}

\begin{abstract}
One reason for the low number of beef consumption in Indonesia in particular Deli Serdang is the least amount of beef offered traders. Therefore, a study was conducted in March 2016 to April 2016 to examine the factors that influence the beef supply in Deli Serdang. The method used was survey with interviews to traders guided by questionnaire. The sample selection started on the personal judgment of researchers who claimed that the selected sample truly represented. Methods of data collection were to collect primary and secondary data.

The results showed that marketing cost factors and profit affected the amount of beef offered. The purchase price was not influenced of a great day and the influence of other commodities not affect partially on the amount of beef offered.
\end{abstract}

\section{Introduction}

Beef is a quite popular commodity as a source of animal protein. However, the quantities of marketable beef are still very low causing the level of public consumption of beef is also low.

Presently, consumption of animal protein in North Sumatra is still lower than standard prescribed by the world food agency (FAO). It is about $2.02 \mathrm{gram} / \mathrm{capita} /$ day or the equivalent of 737 grams/capita/year compare with FAO's standard which is the consumption rate at least $28.2 \mathrm{grams} / \mathrm{capita} /$ day or the equivalent of meat is as much as $10.3 \mathrm{~kg} / \mathrm{capita} /$ year. Referring to these data, it shows that the consumption of meat in North Sumatra is very low compared to the standards prescribed by the FAO [1].

The cow's red meat (beef) is the most commonly consumed by Indonesian. Protein is the greatest content in dry matter causing it has high nutrition. Besides, it has delicious taste to eat.

Close relationship between quantities of marketable beef and consumer demand that it affects each other,encourage researcher to explore the factors that influence the number of deals of meat market in order to know the relationship variable factors (education, marketing costs, the purchase price, a great day gain influence and the influence of other commodities) on the dependent variable amount of beef marketed.

\section{Materials and Methods}

This research was conducted by collecting data from the 6 (six) traditional markets in Deli Serdang North Sumatra province, in March to April 2016.

The method used was a survey by direct interviews with respondents who were guided by a questionnaire[2]. 
The research area was determined by purposive, the sample selection started on the personal judgment of researchers who claimed that the selected sample truly representated [3].

The method of determining the respondents was conducted by sampling AccFirdausta (search) that the respondents that existed at the time attended to the market and were willing to be interviewed[4].

Once the data was collected and tabulated, analyzed in accordance with the hypothesis to be tested. To fulfill the principle BLUE (Best Linear Unbiased Estimator), which is to determine whether the regression coefficient obtained from the corresponding studies had valid or acceptable in order to obtain the best regression model it was necessary to test the classic assumption deviation beforehand.

\subsection{Classical Assumption Deviation Test}

Normality

The multiple linear regression model should assume a disturbance variable (residual) $\mu$ i was normally distributed, which meant that the value of $\mu$ (for each value of Xi) spread

symmetrically because it's a good regression model is to follow the normal line. If this assumption was violated, the regression model was considered invalid by the number of existing samples[5].

Heteroscedasticity

Heteroscedasticity test was aimed to test whether the regression model occurred inequality residual variance of answers among respondents. A good regression model was not heteroskedastisitas. Heteroskidastity caused assessment or estimator became inefficient and determinant coefficient value would be very high[6].

Multikolinearitaswas used to show a linear relationship between the independent variables in the regression model. The smaller correlation between the independent variables, the better the regression model to be acquired [7].

Analysis of the factors that influence the marketing of beef. In a test using multiple linear regression analysis (Multiple Regresion) with six independent variables: education, the purchase price traders, marketing costs, profit / profit, the effect of a particular day, the influence of other commodities. As well as the dependent variable was the amount of meat offered by using the formula:

$$
\mathrm{Y}=a+b 1 \mathrm{x} 1+\mathrm{b} 2 \mathrm{X} 2+\mathrm{b3X} 3+\mathrm{b} 4 \mathrm{X} 4+\mathrm{b5X} 5+\mathrm{b6X} 6+\mu
$$

Information:

$\begin{array}{ll}\mathrm{Y} & : \text { Amount beef sold }(\mathrm{kg} / \text { month). } \\ \alpha & : \text { Coefficient intercept (constant). } \\ \mathrm{b} 1, \mathrm{~b} 2, \mathrm{~b} 3, \mathrm{~b} 4 & : \text { coefficient regression. } \\ \mathrm{X} 1 & : \text { Education } \\ \mathrm{X} 2 & : \text { Marketing costs (IDR / kg) } \\ \mathrm{X} 3 & : \text { The purchase price of the merchant (IDR / kg) } \\ \mathrm{X} 4 & : \text { Profit (Rupiah) } \\ \mathrm{X} 5 & : \text { The influence of the big day } \\ \mathrm{X} 6 & : \text { Effect of other commodities }\end{array}$

Decision-making :

th $<\mathrm{t}$ table, reject $\mathrm{H} 1$; thank $\mathrm{H} 0$

$\mathrm{th}>\mathrm{t}$ table, reject $\mathrm{H} 0$; thank $\mathrm{H} 1$

(H0: there was no effect, H1: no effect) 
Parameters became observation in this study included factors that affectes the supply of beef. Such as education level, traders purchase prices, marketing costs, profit / profit, the influence of a great day on the amount of marketing and the influence of the presence of other commodities (chicken, eggs and fish).

\section{Results and discussion}

3.1. Classical Assumption Test Results

a. Normality test

Normality test could be seen from the graph Histogram residual or Normal PP Plot Graphs with SPSS processing results as follows:

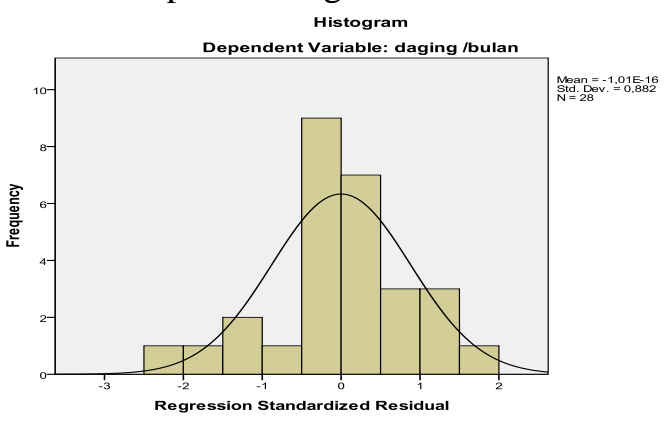

Based on the views graph showed that the average residual was zero. A symmetrical curve where the curve pattern was not leaning to the left or to the right shows that the average residual model of distributed normally. In addition, the normality test could also be seen from the graph Normal PP Plot.

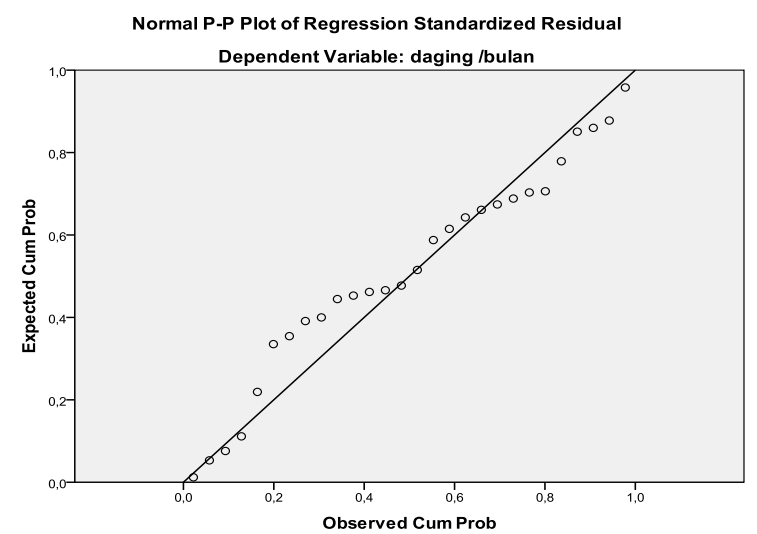

Based on Normal PP Plot Graphs display above, it showed that the point spread around the diagonal line and its distribution follows the diagonal line direction, this indicated that the data was normally distributed model.

b. Test Multicollinearity

Multicollinearity test could be seen from the Tolerance and VIF (Variance Inflation Factor) of each variable

Tolerance and VIF value beef Offer

\begin{tabular}{lll}
\hline \multicolumn{1}{c}{ Variables } & Tolerance & VIF \\
\hline Education & 0.776 & 1,289 \\
Price Buy Merchant & .653 & 1,531 \\
Marketing costs & 0.764 & 1.309 \\
Profit / Gain & .808 & 1,238 \\
influence of the big day & .902 & 1,108 \\
Effect of other commodities & 0.926 & 1,079 \\
\hline
\end{tabular}

(Source: Data are compiled from the output) 
Multikolinearitas symptoms did not occur if the results VIF $<10$ and value tolerance $>0.1$. Based on the results table, it could be seen that the variables of education, the purchase price Traders, Marketing Costs, Profit / Profit, Effect Day, Effect of other goods each VIF its value was $1.289 ; 1,531 ; 1.309 ; 1,238 ; 1,108 ; 1.079<10$. While each of its tolerance value of 0.776 ; $0.653 ; 0.764 ; 0.808 ; 0.902$; and $0.926>0.1$. From these results it could be concluded that no symptoms of multikolinearitas in this equation models.

c. Heteroskidastity Test

Heteokeditas test could be seen from the graph The scatterplotprocessing results with SPSS as follows:

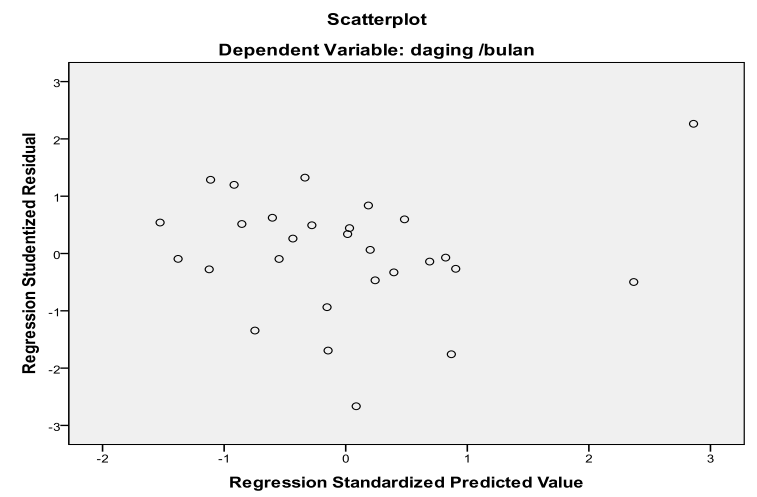

From the scatterplot graph could be concluded that there's no symptoms of heterokedasitas because in the graph above, showed that the distribution of the point spread at random did not form a specific pattern of clear and spread both above and below zero on the $\mathrm{Y}$ axis

\subsection{Model Conformance Test (Test of Goodne ss of Fit)}

a. The coefficient of determination (R2)

From Table obtained value $\mathrm{R}^{2}$ by 0,808 which meant that $80.8 \%$ of the variation dependent variables were the amount of beef sold could be explained by variations in the independent variable which were education, marketing costs, merchant purchase price, profit / gain, the influence of the big day, the influence of other commodities. While the restswere described in the variable and it's ot described in the model.

b. F test (Test Simultaneously

From Table 12. It's noted that there were sig. F 0.000 ( $\mathrm{p}<0.05)$, it could be concluded that the hypothesis was accepted, it meant variable variable effect of education, marketing costs, the purchase price of the merchant, gain / profit, the effect of a particular day, the influence of other commodities partially on the number of deals in the traditional market beef Deli Serdang c. T test (Test Partial)

Tests using two sides was aimed to determine if independent variables (each) partially had a significant effect on the dependent variable with degrees of freedom 20 and with sig testing. 0,025 results obtained by 2.08596 .

\subsection{Factors affecting Beef deals in Deli Serdang}

a. Education, The regression coefficient trader education was less than the table $(0.719$ $<2.08596$ ) with a significant level above 0.05 which was 0.480 could mean that the variable partial education had no effect on the amount of meat offered by the merchant.

From the data above, it showedthat the Sig. for education level traders amounted to 0.480 (p> $0.05)$. Therefore, it could be concluded that the hypothesis was rejected it means variable for education level traders no significant effect on the amount of meat offered traders.

b. Marketing Costs, The regression coefficient merchant marketing costs greater than $t$ table (5.991 <2.08596) with a significant level above 0.05 was 0.000 could mean that the variable 
partial education influenced the amount of beef offered by the merchant. From the data above, it showes that the Sig. for merchant marketing costs amounted to 0.000 ( $p<0.05$ ), so that it could be concluded that the hypothesis was accepted meaning for the variable marketing costs merchants a significant effect on the amount of meat offered traders.

c. Purchase price, Traders purchase price coefficient smaller than t table $(-0.891<2.08596)$ with a significant level above 0.05 was 0.383 could mean that the variable partial education had no effect on the amount of meat offered by the merchant.

From the data above, it showed that the Sig. forpurchasing costs traders amounted to 0.383 ( $\mathrm{p}$ $<0.05$ ) so it could be concluded that the hypothesis was accepted means of variables to purchasing costs traders significant effect on the amount of meat offered traders.

d. Profit / profit, The regression coefficient trader profits greater than t table (4.064>2.08596) with a significant level below 0.05 is 0.001 could mean that the variable partial education influence the amount of beef offered by the merchant.

From the data above, it showed that the Sig. fortrader profits amounted to $0.001(p<0.05)$. It could be concluded that the hypothesis was accepted means of variables to trader profits significant effect on the amount of meat offered traders.

e. The influence of the big day, The influence coefficient bigger smaller than t table $(1,064$ $<2.08596$ ) with a significant level above 0.05 was 0.299 could mean that the variable of influence of the big day partially had no effect on the amount of meat offered by the merchant.

From the data above, it showed that the Sig. forthe influence of the big dayamounted to 0.299 (p>0.05) so it could be concluded that the hypothesis was rejected it meant for the variable ofthe influence of the big day in the significant effect on the amount of meat offered traders.

f. Effect of other commodities, The coefficient influence the availability of a large chicken meat commodity was smaller than $t$ table $(-0.355<2.08596)$ with a significant level above 0.05 was 0.726 , jt could mean that the variable influence the availability of commodity chicken partially had no effect on the amount of meat offered by the merchant.

From the data above, it showed that the Sig. forregression influence the availability of commodity amounted to 0.726 ( $p>0.05$ ). It could be concluded that the hypothesis was rejected, it meant the variable for influencing the availability of commodity had no significant effect on the amount of meat offered traders.

\section{Conclusions}

The research concluded that:

1. The main trade was more experience than education who owned merchant

2. The amount of money issued by the merchant had a relationship proportional to the amount of meat offered

3. Determined price was high thus it affected producers of beef deals

4. Desired gained more and more thus it affected the amount of meat offered by traders

5. The influence of the big day were not affected because when the big day deal price tends to rise

6. Other commodity partial influence did not affect the amount of meat offered

\section{References :}

[1] Getscoop. 2012. Rendah, Konsumsi Protein Hewani. Accessed on http://www.getscoop.com/id/majalah/food-review-indonesia/aug-2012

[2] Daniel, M. 2013. Metode penelitian sosial ekonomi. Bumi Aksara. Jakarta.

[3] Soekartawi. 1995. Analisis usaha tani. Penerbit universitas indonesia. Jakarta. 
[4] Khoirunnisa. 2008. Analisa Permintaan Daging Konsumen Rumah Tangga di Kecamatan Pancoran Mas Kota Depok. Skiripsi. Program Studi Sosial Ekonomi Peternakan. Fakultas Peternakan. IPB. Bogor.

[5] Gujarati, D. 1997. Statistika Ekonometrika. Bumi Aksara. Jakarta.

[6] Priyatno, D. 2009. SPSS Untuk Analisa Korelasi, Regresi, dan Multivariate. Gava Media. Jakarta.

[7] Firdaus, M. 2011. Aplikasi Ekonometrika untuk Data Panel dan Time Series. Bogor. IPB Press. 